ACTA MYCOLOGICA

Vol. 48 (2): 279-285

2013
Dedicated to Professor Maria Ławrynowicz on the occasion of the 45th anniversary of her scientific activity

DOI: $10.5586 / \mathrm{am} .2013 .030$

\title{
First records of Arcyria marginoundulata Nann.-Bremek. \& Y. Yamam. (Myxomycetes) in Poland
}

\author{
ANNA RONIKIER ${ }^{1}$, PIOTR PERZ ${ }^{2}$ and PIOTR CHACHUŁA ${ }^{3}$ \\ ${ }^{1}$ Institute of Botany, Polish Academy of Sciences, Lubicz 46, PL-31-512 Kraków, a.ronikier@botany.pl \\ ${ }^{2}$ Z. Nałkowskiej 12, PL-57-300 Kłodzko, uslugi@data.pl \\ ${ }^{3}$ Pieniński Park Narodowy, Jagiellońska 107B, PL-34-450 Krościenko nad Dunajcem \\ piotrekchacha@gmail.com
}

Ronikier A., Perz P., Chachuła P.: First records of Arcyria marginoundulata Nann.-Bremek. \& Y. Yamam. (Myxomycetes) in Poland. Acta Mycol. 48 (2): 279-285, 2013.

A new to Poland species of a myxomycete, Arcyria marginoundulata, was found at two distant localities in the southern part of the country. Polish specimens are typical and have all important features characteristic of the species: minute, grey, stipitate sporocarps, calyculus concentrically plicate at margin, spiny capillitium and small spores covered with few irregularly distributed larger warts. The species was found growing on alder female catkins. It seems that this substrate is specific for $A$. marginoundulata in Europe.

Key words: Arcyria globosa, Arcyriaceae, the Carpathians, Mycetozoa, Protozoa, the Sudetes

\section{INTRODUCTION}

The genus Arcyria belongs to the order Trichiales and family Arcyriaceae within the class Myxomycetes. It includes 50 species (Lado 2005-2013). Species of Arcyria are characterized by usually stalked sporocarps covered by fugacious peridium remaining at the base as calyculus, pale spores and elastic capillitium forming a network (e.g. Poulain et al. 2011a).

Twelve species of Arcyria have been reported from Poland by Drozdowicz et al. (2003) and one more species, Arcyria imperialis (G. Lister) Q. Wang \& Yu Li has recently been found (see Panek, Romański 2010, as Hemitrichia imperialis G. Lister). Most of these species are common in the country and frequently reported. Only $\mathrm{Ar}$ cyria minuta has been recorded on less than five localities in Poland (Tabacki 1977, but see Drozdowicz et al. 2003, Stojanowska, Panek 2004; Panek, Romański 2010). Most Arcyria species occur on wood of coniferous or deciduous trees, but some of them can be found on other substrata, such as pine needles (A. annulifera, Lado, Pando 1997) or debris of monocotyledons (A. riparia, Poulain et al. 2011a). Arcyria 
marginoundulata is another species that grows on specific substrates: alder female catkins or inflorescences of other trees (Poulain et al. 2011a, b). In the present paper we report this species, hitherto not known from Poland, from two distant localities in the southern part of the country.

\section{MATERIAL AND METHODS}

Material was collected in the field in 2007. Observations and measurements of the morphological characters of mature sporophores were done under stereoscopic microscope Nikon SMZ 1500. The total height, height and width of sporotheca of ten sporophores per collection were measured. Observations of microscopic characters were made on material mounted in Hoyer's medium or water and measurements on material mounted in Hoyer's medium, under a light microscope Nikon Eclipse E-600, with a Nomarski interference contrast. Spore measurements of well developed specimens (30 per collection) were made under an oil-immersion objective $(100 \times)$ and include ornamentation. Specimens are kept in KRAM. Localities of species in Poland were mapped according to the ATPOL grid square system as used by Wojewoda (2000).

For a comparison of $A$. marginoundulata with a similar species, a collection of $A$. globosa Schwein. from KRAM was examined. On the original herbarium label there is information: "ex Herb W.G. Farlow" and the specimen was collected "in involucris Castaneorum". Neither locality nor a date of collection is noted on the herbarium label, only: "Newton" (probably a collector name?) and: "Haüfig" (KRAM M-102).

\section{RESULTS}

\section{SPECIES DESCRIPTION}

Arcyria marginoundulata Nann.-Bremek. \& Y. Yamam.

Figs 1, 2

Sporophores scattered, sporocarpic (Fig. 1a). Sporocarps stipitate, total height 0.26-1.06 mm. Sporotheca globose or slightly wider than high (mean height/width ratio 0.94$), 0.08-0.50 \mathrm{~mm}$ high, $0.10-0.48 \mathrm{~mm}$ wide, first pale red-brownish, then pale greyish when mature. Stalk long, $0.18-0.70 \mathrm{~mm}$, one to four times longer than the sporotheca height, narrowly conical, longitudinally furrowed, pale greyish at apex, rusty-brown to yellow-brown towards the base (Figs 1b-d), yellow-brown by transmitted light. Peridium fugacious, remaining as a small calyculus at sporotheca base. Calyculus greyish, pale yellowish by transmitted light, radially wrinkled, margin thickened, concentrically plicate (Fig. 2a), surface almost smooth, with faint reticulum-like pattern observed under light microscope. Capillitium dense, elastic, slightly expanding, reticulate, large-meshed, in reflected light pale grey, in transmitted light pale yellowish and with yellow to yellow-brown, round inclusions inside swellings when observed in water, hyaline in Hoyer's medium, attached to the calyculus 

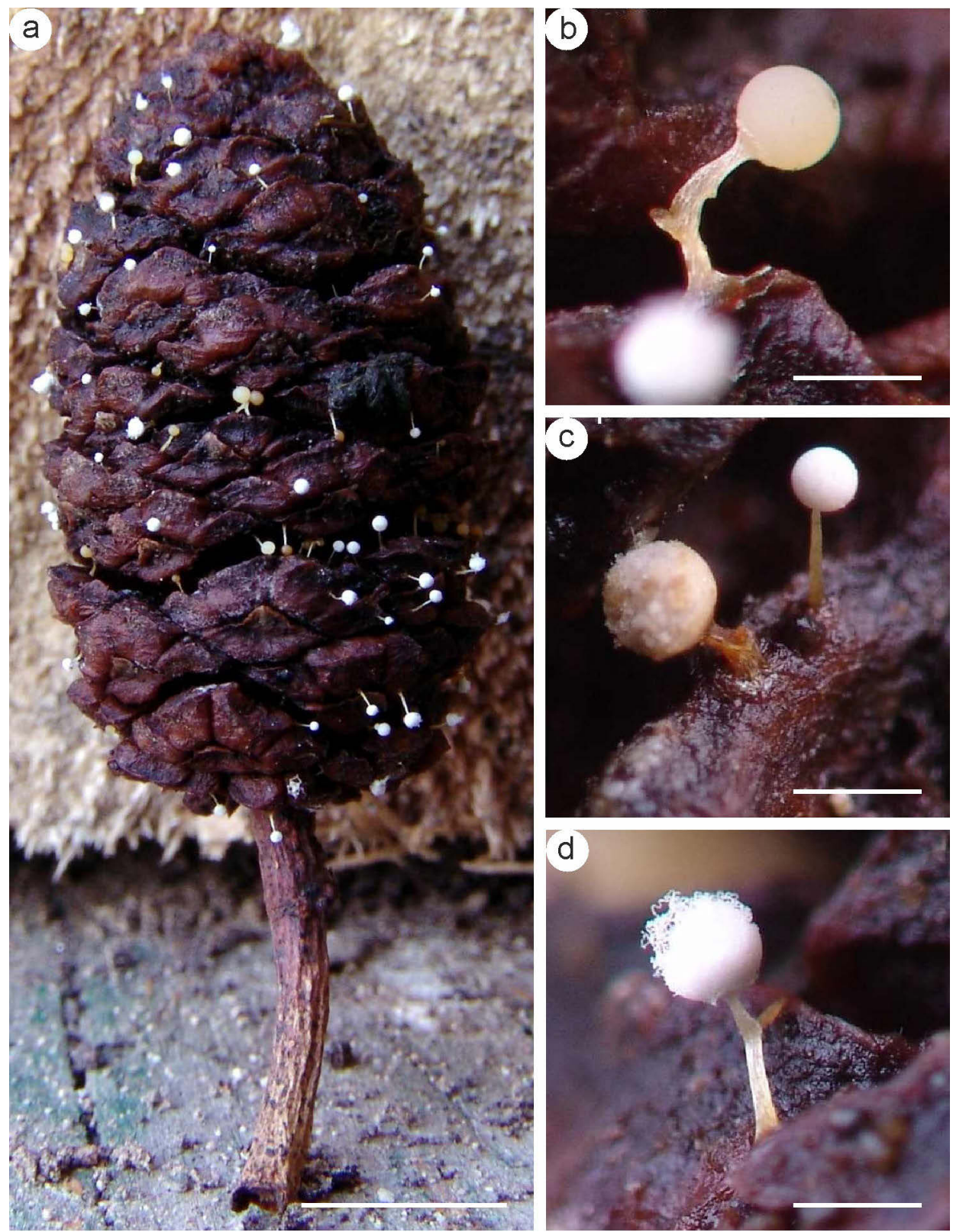

Fig. 1. Arcyria marginoundulata Nann.-Bremek. \& Y. Yamam. coll. KRAM M-1584: a - group of sporophores on an alder female catkin; b - young sporocarp; c, d - mature sporocarps. Scale bars: $\mathrm{a}=5 \mathrm{~mm} ; \mathrm{b}-\mathrm{d}=500 \mu \mathrm{m}$.

surface in several points, threads 1-3 $\mu \mathrm{m}$ wide, with some swellings, densely ornamented with 1-3(4) $\mu \mathrm{m}$ long, spines in outer part of sporotheca, or with low warts connected by a faint reticulum in inner part of sporotheca or close to the calyculus (Fig. 2c-d). Spines conical when observed in Hoyer's medium, blunt or even slightly 

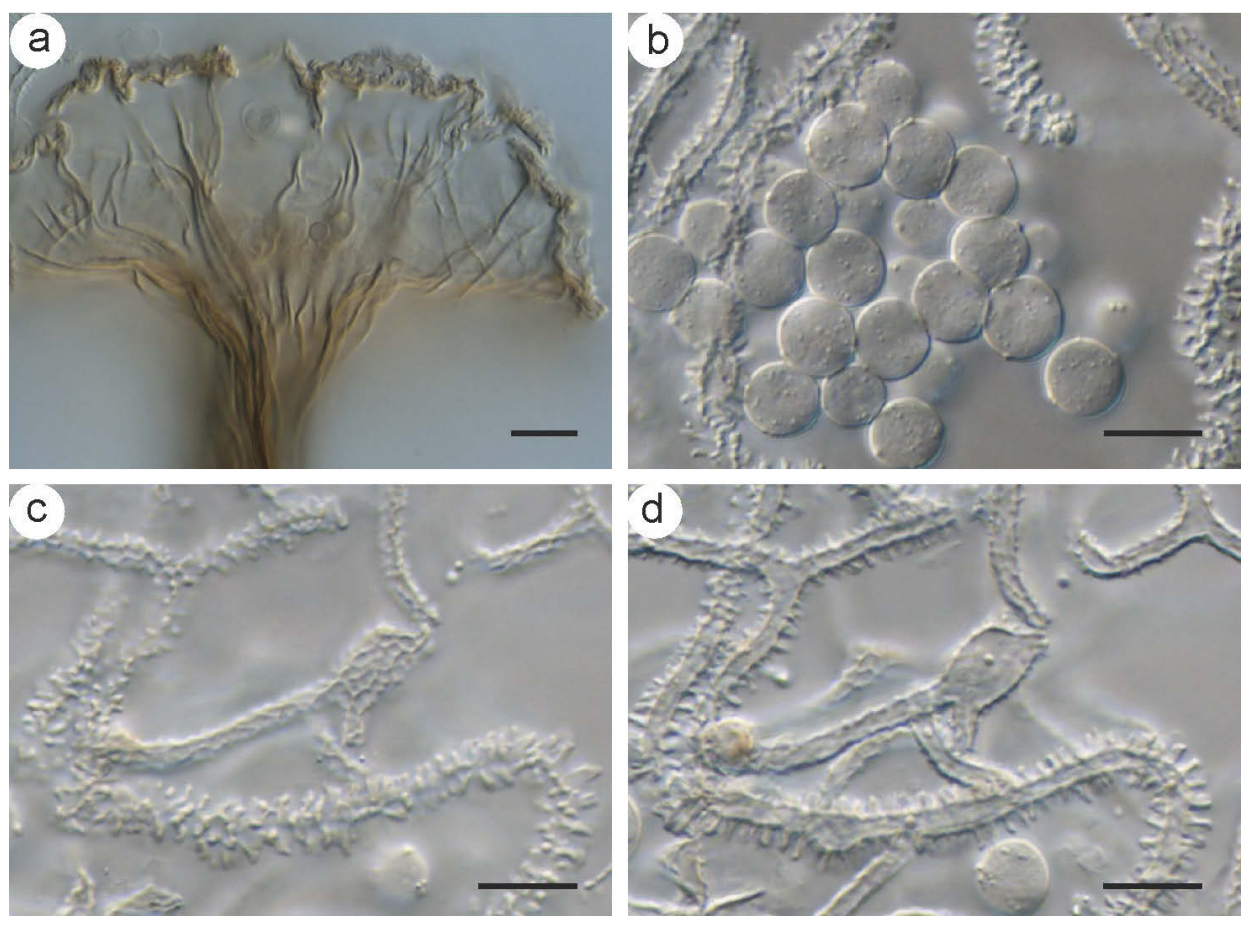

Fig. 2. Arcyria marginoundulata Nann.-Bremek. \& Y. Yamam. coll. KRAM M-1583: a - calyculus observed in Hoyer's medium; b - spores observed in water; c, d-capillitium observed in water (c - top view, d -median view), note different ornamentation type in parts of capillitium: low and reticulate or high and spiny. Scale bar $=10 \mu \mathrm{m}$.

enlarged at apex when observed in water. Spores pale grey in mass, hyaline by transmitted light, (6) 6.5-8 (9.5) $\mu \mathrm{m}$, thin-walled, with loosely and irregularly distributed smaller and larger warts (Fig. 2b).

Localities IN Poland: (1) the Central Sudetes, the Góry Bystrzyckie Mts, the Śnieżnik massif, about $25 \mathrm{~km}$ south from Kłodzko town, Domaszków village, $16^{\circ} 42^{\prime} 13.69$ 'E, $50^{\circ} 12 ' 53.45^{\prime} \mathrm{N}$, alt. $446 \mathrm{~m}$, at the bank of the Domaszkowski Potok stream, under alder tree, on alder female catkins, 22 July 2007, leg. Piotr Perz, KRAM M-1584; (2) the Western Carpathians, the Beskid Mały Mts, surroundings of Wadowice, about $2 \mathrm{~km} \mathrm{SE}$ from Andrychów, Inwałd - „Wapiennik”, 19²3'22” E, 49 50'59,1" N, alt. $390 \mathrm{~m}$, along a stream, among Alnus glutinosa and Urtica sp.; on alder (Alnus glutinosa) female catkins, 26 Aug. 2007 and 01 Oct. 2007, leg. Piotr Chachuła, KRAM M-1583.

Notes: Our specimens nicely fit the original description of Arcyria marginoundulata, however they slightly differ in stalk colour and length; it is dark brown and about $3 / 4$ to $4 / 5$ of the total sporocarp height in the type specimen (Nannenga-Bremekamp, Yamamoto 1983). Also size of spines on capillitium seem to differ from those described from the type material to be about $1 \mu \mathrm{m}$ high (Nannenga-Bremekamp, Yamamoto 1983). We observed spines up to $4 \mu \mathrm{m}$ high in major part of the capillitium, while lower spines (about $1 \mu \mathrm{m}$ high) cover capillitium threads close to the calyculus (Fig. 2c-d). 

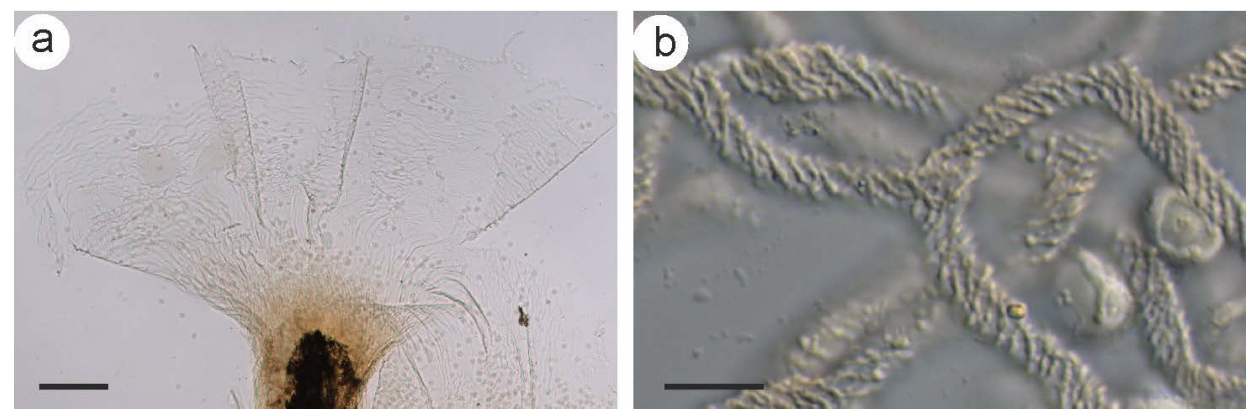

Fig. 3. Arcyria globosa Schwein. coll. KRAM M-102: a - calyculus observed in Hoyer's medium; $\mathrm{b}$ - capillitium observed in water. Scale bars: $\mathrm{a}=100 \mu \mathrm{m}, \mathrm{b}=10 \mu \mathrm{m}$.

We also noted differences in spine shape depending on madium: conical with a pointed apex when observed in Hoyer's medium and blunt or even slightly enlarged at apex when observed in water. The Polish collections are very similar to those described and illustrated by Liu et al. (2002) and Poulain et al. (2011a, b).

Arcyria marginoundulata is one of several pale-coloured species from the genus. Other taxa occurring in temperate Europe differ among others in shorter stalk, larger sporothecae and occurrence of other substrata. One of the most similar to $A$. marginoundulata is $A$. globosa that is the most often reported from chestnut burrs (e.g., Martin, Alexopoulos 1969; Poulain et al. 2011a) but it has also been registered in moist chamber cultures from alder catkins (Adamonyté 2001). Arcyria globosa differs in shorter stalk (about $1 / 2$ of the total sporophore height), larger and more convex calyculus that is not thickened and undulate at margin but thin, radially wrinkled at base and minutely concentrically wrinkled above (Fig. 3a). Additionally, $A$. globosa differs in capillitium ornamentation composed of low spines. Athough in some places the spines merges into reticulum (and then the capillitium ornamentation is similar to those of $A$. marginoundulata from the basal part), the most often they are arranged in right-handed spirals (Fig. 3b).

We found specimens of $A$. marginoundulata at two localities in southern Poland (Fig. 4). Our first specimen was found by the second author on alder female catkins. Then it was searched for by the third author several days later in randomly selected localities with Alnus glutinosa stands and it was easily found. Thus, the species is probably common in Poland but overlooked due to its untypical habitat. Although it was reported from various substrata: inflorescence of Quercus serrata in Japan (Nannenga-Bremekamp, Yamamoto 1983), inflorescence of Castanea crenata in Japan (Poulain et al. 2011a, b), leaf litter, Miscanthus floridulus, Pseudosasa japonica, Cryptomeria japonica, fallen leaves in Taiwan (Liu et al. 2002) and ground litter and coarse woody debris in Texas, USA (Winsett, Stephenson 2012), A marginoundulata seems to be associated with alder female catkins in Europe (see also Müller, Schulz 2010). At our two localities the species occurred exclusively on alder female catkins and it was absent from other litter elements present at the localities. If the species is a frequent inhabitant of this substrate it is probably widespread in Poland, since the distribution of Alnus glutinosa covers almost the whole area of the country (Zajac, Zając 2001). 


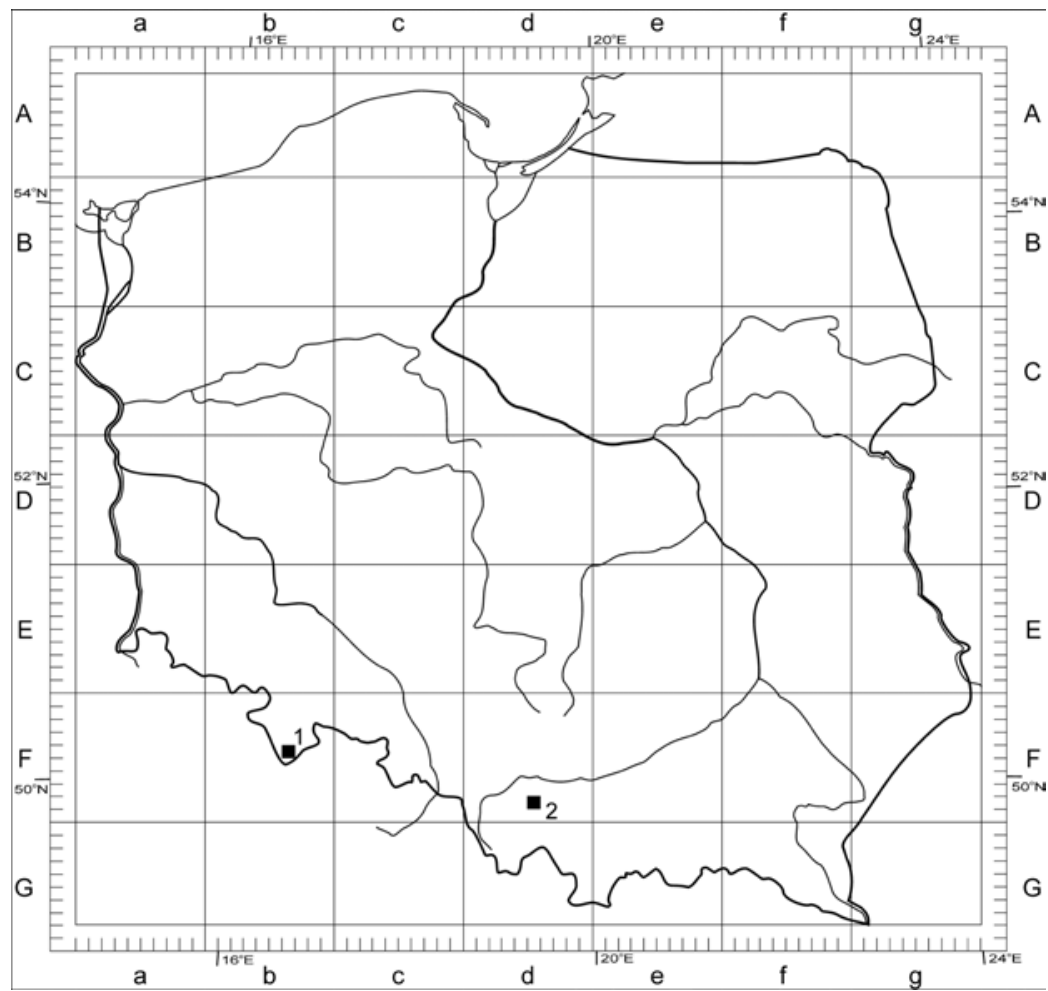

Fig. 4. Distribution of Polish localities of Arcyria marginoundulata Nann.-Bremek. \& Y. Yamam.

Acknowledgments. We thank Anna Drozdowicz for information about localities of Arcyria imperialis, to Michał Ronikier and two reviewers for valuable comments to the manuscript, and to Marian Wysocki and Jacek Wieser for a contour map of Poland. This work was partly financed through the statutory found of the W. Szafer Institute of Botany, Polish Academy of Sciences.

\section{REFERENCES}

Adamonyté G. 2001. Myxomycetes of Viešvilè Strict Nature Reserve (SW Lithuania). 2. Moist chamber cultures. Botanica Lithuanica 7 (2): 179-191.

Drozdowicz A., Ronikier A., Stojanowska W., Panek E. 2003. Myxomycetes of Poland. A Checklist. (In:) Z. Mirek (ed.) Biodiversity of Poland. 10. W. Szafer Institute of Botany, Polish Academy of Sciences, Kraków.

Lado C. 2005-2013. An online nomenclatural information system of Eumycetozoa. http://www.eumycetozoa.com (2013-01-29).

Lado C., Pando F. 1997. Myxomycetes. I. Ceratiomyxales, Echinosteliales, Liceales, Trichiales. Real Jardín Botánico de Madrid and J. Cramer, Madrid, Berlin, Stuttgart.

Liu C.H., Yang F.H., Chang J.H. 2002. Myxomycetes of Taiwan XIV. Three New Records of Trichiales. Taiwania 47: 97-105.

Martin G.W., Alexopoulos C.J. 1969. The Myxomycetes.University of Iowa Press, Iowa City.

Müller H., Schulz W. 2010. Myxomyceten an Fruchtständen von Alnus in Thüringen. Z. Mykol. 76 (1): 75-82. 
Nannenga-Bremekamp N.E., Yamamoto Y. 1983. Additions to the Myxomycetes of Japan. I. Proc. Kon. Ned. Akad. Wetensch. C 86 (2): 207-241.

Panek E., Romański M. 2010. Śluzowce Myxomycetes. (In:) L. Krzysztofiak (ed.). Śluzowce Myxomycetes, grzyby Fungi i mszaki Bryophyta Wigierskiego Parku Narodowego. Przyroda Wigierskiego Parku Narodowego, seria naukowa: 9-85. Stowarzyszenie „Człowiek i Przyroda”, Suwałki.

Poulain M., Meyer M., Bozonnet J. 2011a. Les Myxomycètes. 1. Guide de determination. FMBDS, Sevrier.

Poulain M., Meyer M., Bozonnet J. 2011b. Les Myxomycètes. 2. Planches. FMBDS, Sevrier.

Stojanowska W., Panek E. 2004. Myxomycetes of the nature reserve near Wałbrzych (SW Poland). Part I. List of taxa and quantitative analysis. Acta Mycol. 39 (1): 47-63.

Tabacki A.P. 1977. Slime molds (Myxomycetes) of Silesia beech woods. Acta Biol. 3, Pr. Nauk. UŚL. 175: 58-66.

Winsett K.E., Stephenson S.L. 2012. An annotated checklist of the myxomycetes of the Big Thicket National Preserve, Texas. J. Bot. Res. Ints. Texas 6 (1): 287-298.

Wojewoda W. (ed.) 2000. Atlas of the Geographical Distribution of Fungi in Poland. 1. W. Szafer Institute of Botany, Polish Academy of Sciences, Kraków.

Zając M., Zając A. (eds.) 2001. Distribution Atlas of Vascular Plants in Poland. Laboratory of Computer Chorology, Institute of Botany, Jagiellonian University, Kraków.

\section{Pierwsze stanowiska Arcyria marginoundulata Nann.-Bremek. \& Y. Yamam. (Myxomycetes) w Polsce}

\section{Streszczenie}

Nowy dla Polski gatunek śluzowca, Arcyria marginoundulata, charakteryzujący się białopopielatymi zarodniami niewielkich rozmiarów (do ok. 0,5 $\mathrm{mm}$ średnicy) i występowaniem na szyszkach olszy, został znaleziony po raz pierwszy w Polsce, na dwóch stanowiskach w południowej części kraju: w Sudetach (Góry Bystrzyckie) oraz w Karpatach (Beskid Mały). W niniejszej pracy przedstawiono opis polskich okazów oraz ich stanowisk, a także porównano $A$. marginoundulata z najbardziej podobnym gatunkiem, $A$. globosa, który może występować na podobnym substracie. Arcyria marginoundulata jest gatunkiem kosmopolitycznym i mimo że znajdowanym na różnych substratach, w Europie wydaje się być przywiązany do szyszek Alnus. Możliwe, że gatunek jest pospolity w kraju, ale nieodnotowywany z powodu małych rozmiarów zarodni oraz występowania na specyficznym i rzadko badanym substracie. 